\title{
Erratum: External rostral characters for differentiation of sexes in the biological control agent Mecinus janthinus (Coleoptera: Curculionidae)
}

\author{
Marjolein Schat, ${ }^{1}$ Sharlene E. Sing, Robert K.D. Peterson \\ Department of Land Resources and Environmental Sciences, Montana State University, \\ Bozeman, Montana 59717-3120, United States of America
}

\section{Ref.: Can. Entomol. 139(3): 354-357}

In the above paper, on page 354 , it was brought to our attention that the abstract was poorly translated into French by the authors. The following is how the résumé should read:

Résumé-Le charançon perceur de tiges, Mecinus janthinus (Germar), est un agent de lutte biologique classique bien établi et prometteur pour le contrôle d'une mauvaise herbe exotique invasive, la linaire à feuilles larges (Linaria dalmatica (L.) Mill.) (Scrophulariaceae). Dans cet article, nous présentons des caractéristiques du rostre faciles à identifier, permettant la différenciation, à faible grossissement, des sexes de charançons perceurs de tiges vivants. Ces caractéristiques peuvent être utilisées par des travailleurs possédant une formation minimale afin d'identifier correctement le sexe des charançons. Ceci permettra donc une détermination rapide de la proportion des sexes des populations sur le terrain, améliorant ainsi les délais de capture, puis de lâchers.

The Editor-in-Chief regrets the error and thanks Véronique Martel and the Bilingualism Committee of the Entomological Society of Canada for correcting the résumé.

Received 3 June 2007. Accepted 3 June 2007.

${ }^{1}$ Corresponding author (e-mail: mschat@montana.edu). 